\title{
THE IMPACT OF SPANISH INQUISITION ON ISLAMIC CIVILIZATION
}

\author{
RASYIDAH ARSHAD, SYAIDATUN NAZIRAH ABU ZAHRIN* \& NURUL \\ SHAHIRAH ABDUL SAMAD
}

\begin{abstract}
The Spanish Inquisition was established as an official body blessed by the Roman Catholic Church, because the Catholic rulers Isabella and Ferdinand were determined to rid Spain of any heretics or non-Catholics. The greatest impact of the inquisition was the banishment of Islam from Spain. Spain has been a vibrant civilization for six centuries, serving as the shield of other religions. There was no divine guidance left untouched, or even a small group of believers left. It has resulted in Islam being delayed in Christian Europe for several decades. Even though Muslims have come to Europe in the last two centuries, Islam has been practiced as a personal religion of worship and prayer, but never as a government that has protected and enriched the lives of all religions, as we have seen during the Muslim rule of Andalusia. The aim of this paper is specifically to discuss the policies of the Spanish Inquisition on the Muslims in Andalusia. Muslim policies are discussed in great depth compared to other groups, because they were the majority and most resistant to policies. The analysis of the impact of the Inquisition is important to understand how Islam was eradicated from the Spanish society and later re-emerged as a significant presence in Spain.
\end{abstract}

Keywords: Spanish inquisition; Islamic civilization; Islam; History.

\section{INTRODUCTION}

Andalus is the Arabic name for the Iberian Peninsula which is now commonly known as Spain and Portugal. It was inhabited by people long before the coming of the Vandals and the Goths, and even the Celts that preceded them. Andalus was originally the Arabic word for the Vandals, and by changing the last letter, from a shin to sin, it became Andalus (Stearns 2009)

Undoubtedly, the most important event in medieval Spain's history and what made it unique in comparison with other European countries was the Muslim conquest of almost the entire Peninsula in 711. While Islam has been the dominant force for seven centuries, and the majority of the people of Andalus were Muslims, they coexist with Christians and Jews. After the crushing defeat of the Muwahidun in the battle of Las Navas de Tolosa in 1212, which destroyed hundreds of thousands of Muslims, the triumphant Trinity Christian army captured the whole of Andalusia, except Granada. (Rifqi and Zamzami 2016)

The Spanish Inquisition was established as an official institution blessed by the Roman Catholic church, because the Catholic rulers Isabella and Ferdinand were determined to rid Spain of any heretics or non-Catholics. Inquisition means investigation. Thus, the main aim of the Inquisition was to inspect the authenticity of those who had been converted to Catholicism. History has told us, however, that inquisition was racial genocide and religious fanaticism at its worst. (Thomson and 'Ata'ur Rahim 1996) (as-Sirjani 2013).

This paper intends to discuss specifically the policies of the Spanish Inquisition on the Muslims in Andalusia. The policies on the Muslims are discussed in many details compared to 
the other groups since they were the majority and most resistant to the policies. An analysis of the impact of the Inquisition is equally important to the whole discussion.

\section{Terms}

In studying the history of Andalus, one of the most intriguing points are the different terms used to describe Muslims, especially in Western literature. The most popular synonym for Muslims is 'Moors'. Technically, it refers to the Latin word 'Maurus', which means dark complexion. However, the term moors have been and is often used by historians to describe the Muslims either before, during, or after their presence in the Iberian Peninsula. (Stearns 2010) (Thomson and 'Ata'ur Rahim 1996).

Other than the Moors, the Muslims of Andalusia are commonly referred to as Mudajares and Moriscos. Initially, the term Mudajares is used by true Muslims as a form of ridicule for those Muslims who made alliances with Trinitarian Christians and fought their Muslim brothers with the help of these Christians. Eventually, it was used to identify all Muslims living outside the state of Granada. (Thomson and 'Ata'ur Rahim 1996).

Whereas the term Moriscos were used to refer to the Mudajares who were forcibly baptized especially after the fall of Granada in 1492 (Bennison 2016). The question that a researcher of Andalus history should be asking is why the different terms are used to describe Muslims. A quick conclusion would be that it indicated the main processes which Islam was watered down before it was banished from Spain.

\section{THE END OF THE MUDAJARES IN SPAIN}

\section{Policy of Persecutions}

The Trinitarian Christians began their harsh treatment of Muslims and Jews as soon as they became more established in the land. The Jews and the Mudajares were accepted only in so far as Christians relied on them for their needs (as-Sirjani 2013). History unreservedly agreed that the Muslims and the Jews were the backbone of the country. The Jews were in commerce and finance, so they possess a vast amount of wealth. The Muslims were involved in crafts and agriculture and were a disciplined labor force. In the first wave of persecution, since the Jews were a dirty rich man, they were an obvious target of greed. The population of the Muslims were more than the Jews, so the process of banishing them was longer. Another reason for the later banishment of Muslims from Andalusian life was that they were involved in all kinds of trades and fashioned all the necessities of ordinary everyday life. The Trinitarian Christians relied on their labor to meet the basic needs of their food, shelter, and clothing (Djurfeldt 1993).

The Christians ' initial strategy was to try to contain the Muslims by making them loyal servants. The Christians forced the Muslims to strip themselves of their way of life, while at the same time maintaining their value as slaves. There was a popular saying, 'Moors more money', taking the Muslims as a money machine. Ironically, the Muslims were hated by the Trinitarian Christians for their economic dependence on them (Puteh Noraihan 2011; Djurfeldt 1993).

Christian hatred of Muslims, however, is not based on economic factors alone. It is also because the Church has rejected the existence of the prophets after Jesus. The stand of the Muslims on the Prophethood of Muhammad was against the official stand of the Church. The Roman Catholic Church, therefore, set out to change the minds of Muslims and Jews about their knowledge, belief, and way of life (Deardorff 2017). 
Due to the inquisition in Spain, southern France's unitary Paulicianism was effectively wiped out (Simms 2015). So the Christians felt that they could do the same thing successfully in Spain. Several examples of the persecution of Muslims in the early stages have been:

- In 1216, to humiliate the Muslims, the Lutheran Council decreed distinctive garments and badges (san Benito) to be worn by Muslims and Jews. It was usually a long yellow dress with one or two diagonal crosses on it (Kılıç 2016). This strategy was risky, and Muslims and Jews were subject to threats and ill-treatment. Besides, if they were expelled from the region, they faced robbery and murder on the highway, as well as persecution everywhere they went (Deardorff 2017).

- In 1248, Pope Innocent IV instructed the King of Aragon to' allow no Moors save as slaves.' The rights and freedom of Muslims have therefore been restricted. Nor were Christians allowed to engage in commercial dealings with Muslims (Deardorff 2017).

- In 1250, it was decreed that a license should be obtained before purchase or sale from Muslims, unless a license had been obtained before that date (Kıliç 2016).

Despite these humiliations and restrictions on Muslims, many of them continued to hold on to their Islamic way of life. (Thomson and 'Ata'ur Rahim 1996) (as-Sirjani 2013).

- In 1312, the Council of Vienna complained about the worship of the Muslims, specifically the Azan, and about the worship of the priest or saint, referring to the Prophet Muhammad. The Muslims have been given the ultimatum to embrace Christianity or to suffer punishment. This order has been obeyed piecemeal for several years. (Thomson and 'Ata'ur Rahim 1996)

- In 1329, the Council of Tarragona ordered the adoption of a resolution within 2 months or otherwise faced the penalty of ex-communication. With this verdict, the persecution of the Muslims escalated (Deardorff 2017)

- In 1337, the Bishop of Tarragona requested Pope Benedict XII to allow the nobles to confiscate and sell the property and wealth of the Muslims. This was recognized and practiced by the Roman Catholic Church until they decided to banish Jews and Muslims from Spain. Between 1385 and 1387, more laws were enacted to subject Muslims to slavery and humiliation and degradation (Kılıç 2016).

- In 1388, a decree required the Muslims to kneel when the Trinitarian sacraments went through the streets. Muslims were also exempted from working on Christian holy days and Sundays and were forced to work on other days, including Fridays (Thomson and 'Ata'ur Rahim 1996).

- In 1412, the height of early legislation reached its peak to reduce the number of Muslims and Jews to wretched slavery. It was quoted:

\footnotetext{
"It was decreed that Jews and Moors should wear distinguishing badges, be deprived of the right to hold office or possess titles, and should not change their domicile. Also, they were excluded from various trades such as those of grocers, carpenters, tailors and butchers; could not bear arms or hire Christians to work for them; we're not allowed to eat, drink, bathe or even talk with Christians; and were forbidden to wear but coarse clothes"
}

(Thomson and 'Ata'ur Rahim 1996)

After this edict, the living quarters of the Muslims in the cities and towns were isolated; walled compounds were built, namely Juderias for the Jews and Morerias for the Muslims (Remensnyder 2016). 
In 1483, to ensure the complete banishment of Muslims and Jews, the Tribunal of Inquisition in Spain was officially established and blessed by the Pope. Their main objectives were to domesticate the' heretics ' slaves of northern Spain and ultimately to subdue the slaves of Granada (Chachia 2017).

The heretics here refer to those who have betrayed their baptism, so that the court may exercise jurisdiction over those who have baptized. Victims accused of heresy often claimed that they had never been baptized. The Tribunal, therefore, set out to baptize as many Muslims and Jews as possible in the shortest possible time. This was achieved by giving them an ultimatum between baptism and death. As a result, there were three scenarios-those who fought were killed, those who survived but refused to be baptized were tortured and killed, and the others were baptized (Chachia 2017) .

For those who were baptized, if they were found to be contrary to any of the Roman Catholic teachings, they would be persecuted as heretics. Thus, the introduction of the Spanish Inquisition made it impossible for Muslims and Jews to forge their forced conversion to Catholicism. Any outward signs of rejection of the official religion or secret practice of Islam at home will be punishable by death (Kılıç 2016).

\section{The Edict of Grace}

One of the methods of pressuring Muslims and Jews to be baptized was the use of the Edicts of Grace, which were used to instill fear and suspicion in the hearts of the people. The game was such that a person is' to denounce himself and everyone he knows to be heretics in the time of Grace, and to zealously announces his intention to become a Christian.' In exchange, they avoided property damages, torture, and death (Thomson and 'Ata'ur Rahim 1996).

This strategy, however, has set the Muslim and Jewish communities back on fire. They were divided, and they were made to turn against each other. Although one would have denounced himself, that was not enough to ensure the safety of one and his family. He had to share the names of all the others he 'd considered to be a heretic. It was, therefore, with the knowledge that any man who refused to denounce, that if someone else had denounced him, he would probably be put to death, and his family would suffer, and would be deprived of their land, and of any means of subsistence other than slavery (Robert 2013).

To ensure obedience to the edict throughout the country, the Inquisitors traveled from town to town. Their arrival was pronounced thirty to forty days before their arrival. Once the time of grace had ended for a certain village, the Inquisitors would turn up and arrest all those who had been denounced by others but had not denounced themselves. As a result, people remained in jail for a long time without trial (Robert 2013).

\section{Forms of torture}

Not only did the prisoners languish in prisons, but they had to go through various forms of torture that were cruel but successful. There were three main tortures used by the Inquisitors:' Garrucha, torca and Potro'. Torture of Garrucha usually caused dislocated joints and tendons to the victims. The Garrucha or the pulley would have heavy weights attached to his hands. His arms were tied behind his back and fastened to a rope threaded to a pulley attached to the torture chamber ceiling. The victim would slowly be drawn up into the air before he could suddenly drop a few feet in the middle of the air (Dedieu 2010; Simms 2015).

In the torment of the torch or the torture of water, the victim was placed on an escalera or potro - a kind of trestle, with sharp edged rungs across it like a ladder. It slanted so that the 
head is lower than the feet and, at the lower end was a depression in which the head sank, while an iron band around the forehead or throat kept it immovable. (Puteh Noraihan 2011). Subsequently, the victim's mouth was covered with a rag. Large amounts of water were then poured into the victim's mouth, and he was forced to swallow it with the cloth. (Kilic 2016).

In the torture of the potro or the rack, the victim's ankle was bound to a wooden frame with a rough cord, which was then tightened by a hand. Stretched in this position, a cord was passed around the arms, which the executioner wound around himself and threw himself backward, casting his whole weight and pushing with his foot against the potro. Subsequently the torturers would use the cord to cut through the skin and muscle to the bone, while the body of the victim was stretched as in a rack, between it and the cords at the feet. This was repeated six or eight times, on different parts of the arms, and the victims usually faints, especially if they are women. (Kılıç 2016; Simms 2015).

The Inquisitors used flogging during long sessions of the 'questioning'. Once they have decided the number of strokes on the 'heretic', lapsed Moor' or 'judaizer', the victims will appear before the public executioner will bridles or nooses around their necks. They will then be taken on a parade around town, with a guard of pikemen and a secretary to report on the spectacle, while the hooded executioner carried out the flogging on the exposed back skin of the victims (Puteh Noraihan 2011).

No one was exempt from torture; men, women, and even children were tortured. Of course, the tortured referred to above was not exhaustive. Many other forms of torture have been carried out by the Inquisitors. The effect of the terms of grace on the Muslim community has been devastating. The community became divided, and as soon as their unity was broken, many of the individual members were forced to become Christians to remain alive and to survive as slaves (Simms 2015).

From the point of view of the cruelty and oppression perpetrated by the Spanish acquisition of the Muslim and Jewish communities in Spain. The analysis of the forms and comparisons of the atrocities committed by them such as the process of interrogation and the execution of punishment on inquiry are very different from the process in modern courts. Torture in the inclusion is indeed allowed with the aim of obtaining permission from the accused. The problem is, with such torture people who admit they are certainly not the only ones who are truly 'guilty,' but also those who cannot stand the torment. Torture and punishment were intended to decreased one's faith (Iman) and convert to Christian.

\section{Fresh Campaigns Against the Mudajares}

By the beginning of the 16th century, the entire Iberian Peninsula had been under the rule of the Trinitarian Christians, and the presence of Islam was no longer possible. There were still Muslims, especially in the remote mountainous area of what was formerly Muslim Andalusia, but after three centuries of war and persecution, most Muslims were either dead or gone.

\footnotetext{
"Ten years after the expulsion of the Jews, Isabella on $12^{\text {th }}$ February 1502, issued a royal order giving all remaining Muslims in the realms of Castile the choice between baptism and expulsion. The majority of the native Muslim communities, the Mudajares, chose to stay and be baptized. How free such a choice was being illustrated by the fact that emigration was made impossible. The historian Galindez de Carvajal says that although Muslims were technically allowed to leave if they chose, in practice, the authorities would not allow them to go and instead forced them to accept baptism. Under such conditions, the mass of the remaining Muslim population of Castile came into the Catholic fold"
} 
The immediate policy was therefore to convert the Mudajares of Castille. The process was accelerated by dividing their families. Under the decree, all males and females under the age of twelve were separated from their families and handed over to the Roman Catholic Church to be brought up as Trinitarian Christians (Deardorff 2017).

The role of the Germania Revolts was another method of accelerating the conversion. The Germanis conceived the idea of baptizing them by force, thus giving them equal rights as Trinitarian Christians. However, this was not a matter of religious zeal, but rather of an act of hostility towards the nobles, whom they believed had benefited greatly from the presence of the mudajars (Remensnyder 2016). Their campaign of forced baptism was one of devastation, robbery, murder, and baptism. In Constentaina, for example, the Germainas ran amok and killed all the Muslims in the mosque and began an orgy of murder, rape, and robbery. Those who survived have been baptized. Thus, by 1526, Morisco Spain was a reality (Remensnyder 2016).

By the beginning of 1526, the entire remaining Muslim population had been baptized in one way or another. However, in January 1526, the leaders of the Moriscos were able to obtain from the Crown and the Inquisitor General Manrique a secret Concordia, or an agreement that, if they submitted to baptism, they would be free forty years from any persecution by the Holy Office, since it would be impossible for them to break all their old customs at once. (Deardorff 2017; Simms 2015). The Muslims paid 50,000 ducats to Charles $\mathrm{V}$ for the deal. The Inquisitors, however, argued that their way around this arrangement would mean that they could put to court all converts who had slipped back into their Muslim rites and customs (Kılıç 2016).

From 1528 to 1530 , therefore, there were one hundred and six cases of heresy cited before the Inquisition of Valencia. In 1531 there were fifty - eight trials for heresy, and that year around forty - five people were burned for the same offense. Around 1532 and 1540, the number of people tried for heresy was 441. These figures would include several Jewish conversos, but most of them were certainly Moriscos. Thus, for 12 years around 1528 and 1540, an average of at least one Morisco per day was burned alive in Valencia alone for refusing to refute what he claimed: that there is no god but Allah and that Muhammad is the Messenger of Allah (Thomson and 'Ata'ur Rahim 1996).

The Spanish reaction to religious enthusiasm, in addition to its theological and natural philosophical aspects, also comprised a legal component. In the late sixteenth century the Spanish Inquisition began to prosecute cases of simulated sanctity, and this new crime of "feigning revelations" (fingir revelaciones) went on to become a fixture on the dockets of inquisition tribunals not only in Spain but throughout the Catholic world (Schutte 2001).

The burning of 'prohibited books' in the case of Muslims, copies of the Quran, hadits, tafseer, Arabic manuscripts etc was an old western 'custom respectable by its antiquity' (Puteh Noraihan, 2011). As stated in the edict of 1567,

\footnotetext{
"By this measure, all the rites, customs, and language of the Moriscos were forbidden under penalty. Books in Arabic were destroyed, and Moorish clothes were forbidden. The list of prohibitions amounted to the suppression of every national characteristic of the Moriscos."
}

(Thomson and 'Ata'ur Rahim 1996)

Even the last of the public baths, which the Muslims had constructed everywhere when they first came to Spain, had been ruined.

It is difficult to document all the policies of persecution, assassination, burning alive, banishing Muslim incidents, not only because they were so numerous, but we believed that the official historians refused to give information. As brutal and cruel as these schemes were, it seemed that no one's conscience was disturbed. In reality, many of the learned theologians who 
believed that the acts were not contrary to the teachings of the Trinitarian Christianity (Kılıç 2016)

\section{$17^{\text {th }}$ Century Persecution}

On September 27, 1609, Archbishop Ribera announced the decree of expulsion. The Moriscos, who were officially Christian, were not permitted to follow Islam freely because they had been forcibly baptized and were legally considered to be members of the Roman Catholic Church. Only those who acted like Trinitarian Christians, however, were not allowed to stay because they were Moriscos. (Chachia 2017)

The Expulsion was the last effort to rid Spain of any Muslims and their identity. It is not known how many Moriscos have been exiled. The estimated range is between 600,000 and 3 million. Whatever the figure, the fact remains that the Muslims were in Andalusia, the Mudajeras were in Andalusia, the Moriscos were in Andalusia, and they were forcibly expelled from it (Chachia 2017; Kılıç 2016).

\section{IMPACT OF THE SPANISH INQUISITION ON ISLAMIC CIVILISATION}

The Spanish Inquisition has had a great and long - term effect. It first caused financial distress for the nobles and landowners. In the years before the Inquisition, the bourgeoisie and the official Roman Catholic Church themselves made money from lending money to the Moriscos at high-interest rates and charging them high rents on land confiscated from Muslims and Jews. The Spanish Inquisition Tribunals themselves were the most affected. Eventually, due to poor business, the courts were declared bankrupt (Djurfeldt 1993). Moreover, when the Tribunals decided to expel the Muslims, the entire agricultural labor force of the country and skilled craftsmen were lost, and many industries were therefore unable to function.

Andalusia has been a stable society for almost 700 years, where people of different faiths coexist and peacefully practice their faith. Though different from Islam, Christianity, and Judaism, it was the worship of one God that might have spiritually maintained Andalusia and made it prosperous. With the Inquisition, and finally, with the expulsion of the followers of Prophet Muhammad and Prophet Isa, Andalusia became a spiritual desert. There was a complete absence in the worship of the One God as represented by all the Prophets, i.e. no Muslims, no United Christians, and no Jews. For those who remained, they were limited within the official religion of Trinity Christianity, sadly by persecution, censorship, and injustice. (asSirjani 2013)

Thus, with the absence of worship of one divine God, Spain was plunged into superstition and ignorance. There was no divine unity, and therefore witchcraft sprang through. The Christian Inquisition persecuted the witches because there were no Jews and Muslims heretics to persecute.

The Trinitarian Christians refer to their Inquisition as Opus Dei or the work of God. Since it was not based on the teachings of the prophet Isa or Jesus, the order was coercive and oppressive. Following the dissolution of the Inquisition, the colonial invasion of Trinitarian Christians in Europe, the sub-continent of India, Arab countries and Asia has reported an ongoing record of prohibitions, executions, murders and mass murders by the Trinitarian Church. Examples of modern crusaders include the horrific massacre of Sufis in Morocco in the 19th century, the mass murder of the Sansui communities in southern Libya by French forces working closely with Trinitarian Christians, and the tragic murder of three great Nigerian Muslim leaders closely linked to the Vatican. (Thomson and 'Ata'ur Rahim 1996) 
Thus, without divine guidance and punitive steps, people are disillusioned with religion. They resorted to logical explanations and understanding of themselves and of the world. The terrible result was a complete rejection of official religion and an understanding of reality through empirical methods of observation and deduction.

Unfortunately, the latest empirical approach to what became known as' science' culminated in Darwin's theory of evolution. This is a rejection of the fundamental message that every prophet was sent since Adam the prophet. Many modern scientists have also acknowledged that much of Western learning and knowledge stems from the discoveries of the Muslims in Andalusia.

The biggest impact of the Inquisition was the banishment of Islam from Spain. Spain has been a rich civilization for six centuries, acting as an umbrella for other faiths. There was no prophetic guidance left untouched, nor even a small group of believers. It has resulted in Islam being delayed in Christian Europe for several centuries. Although Muslims have come to Europe in the last two centuries, Islam has been practiced as a personal religion of worship and prayer, but never as a government that has protected and enriched the lives of all religions, as we saw during the Muslim rule of Andalusia.

The ethnic cleansing and genocide of the Muslims did not stop with Andalusia. In fact in this recent century, the world have witnessed gruesome attacks of ethnic cleansing on the Muslims of Bosnia from 1992-1996, followed by Ambon in 1997, the persecution of the Syrians and the Rohingyas of Myanmar, with no definite solutions by world leaders. The Muslim world has changed, but do we learn from history?

\section{BETTER PICTURE OF ISLAM IN CONTEMPORARY SPAIN}

Islamic Spain, or Al-Andalus, was a major centre of Muslim civilization for nearly eight centuries during Islam's 'Golden Age'. Although the Spanish Inquisition had the eventual effect of eradicating Islam from Spanish society, Spain's Muslim heritage remains apparent in its culture, language and architecture. Consequently, some view Spain as a potential bridge between Islam and the West. This view has been put to task by the re-emergence of a significant Muslim presence in Spain over the past several decades, primarily due to high levels of immigration from Muslim-majority countries in Africa and South Asia (Astor 2014).

The growth of Spain's Muslim population has coincided with several profound political and social transformations within Spanish society, including the transition from dictatorship to democracy and the shift from religious homogeneity to plurality. Amid these transformations, new frameworks for governing religious diversity have emerged at the national, regional and local levels. These frameworks have had a significant impact on the accommodation of Spain's Muslim population, as well as the manner in which Muslims have organised and made claims upon the state (Astor 2014).

As a result of rising rates of immigration from Muslim-majority countries during this period, the number of Muslims residing in Spain increased precipitously. Spain's Moroccan population, which numbered just 90,000 in 1996, grew to 420,000 by 2004. Pakistani, Senegalese and Algerian communities also came to have a significant presence in certain parts of the country. Islam's transformation into a minority religion with a substantial following generated increasing public concern regarding its growing presence in Spain (Astor 2014). Even though we witness great changes in the Muslim world history, especially in Spain, the Muslims should learn from history and do not repeat the same mistakes due to the misleadership, decline in believe towards Allah SWT and Prophet Muhammad pbuh. 


\section{CONCLUSION}

The period of both the Medieval and the Spanish Inquisition lasted six centuries; it took about the same time for Islam to flourish in Andalusia. A marked difference was how Trinity Christians developed their way of life in Andalusia. It was a program of destruction and persecution by the strict enforcement of the official religion. On the other hand, there was a flowering of life, grounded in the worship of one God, which made peaceful co-existence possible under the rule of the Muslim. Secularists and orientalists have tried to play down the role of religion in world civilization. However, history has shown that those who have affirmed Divine Unity and prophetic guidance are the ones who bring justice and mercy to mankind. This is true of the past, the present and the future.

\section{REFERENCES}

Schutte, A.J. 2001. Aspiring Saints: Pretense of Holiness, Inquisition, and Gender in the Republic of Venice, 1618-1750. JHU Press.

Astor, A. 2014. Religious governance and the accommodation of Islam in contemporary Spain. Journal of Ethnic and Migration Studies, 40(11): 1716-1735.

as-Sirjani, R. 2013. Andalusia. jakarta: Pustaka al-Kautsar.

Chachia, H. E., 2017. The moment of choice: the Moriscos on the border of Christianity and Islam. In Conversion and Islam in the Early Modern Mediterranean: 141-166.

Deardorff, M. 2017. The Ties That Bind: Intermarriage between Moriscos and Old Christians in Early Modern Spain, 1526-1614. Journal of Family History 42(3): 250-270.

Djurfeldt, G. 1993. Classes as clients of the state: landlords and labourers in Andalusia. Comparative Studies in Society and History 35(1): 159-182.

Handler, A. 1967. The Zirids of Granada. Michigan: Colombia University.

Bennison, A. K., 2016. Almoravid and Almohad Empires. Edinburgh University Press.

Puteh Noraihan Abdul Rahman. 2011. "Muslims of Andalus after the Fall of Granada. The Catholic policy of destruction of Islam (1492-1525C.E.)." Kuala Lumpur: International Islamic University Malaysia.

Remensnyder, A. G. 2016. The entangling and disentangling of Islam and Christianity in the churches of Castile and Aragon (11th-16th centuries). Transkulturelle Verflechtungsprozesse in Der Vormoderne 123-140.

Roth, N. 1994. Jews, Visigoths \& Muslims in Medieval Spain - cooperation and conflict. Leiden: E.J.Brill.

Simms, N. 2015. Forerunner of the science of psychoanalysis? An essay on the Spanish and Portuguese Inquisition. The Journal of psychohistory 42(4): 295.

Stearns, J. 2009. Representing and Remembering al-Andalus: Some Historical Considerations Regarding the End of Time and the Making of Nostalgia. Medieval Encounters 15(2-4): 355-374.

Thomson, A. \& M. A., Rahim. 1996. Islam in Andalus. London: Ta Ha Publications.

\section{RASYIDAH ARSHAD}

Faculty of Islamic Revealed Knowledge and Human Sciences

International Islamic University Malaysia.

53100 Selangor, Malaysia

Email: rasyidah.arshad2020@gmail.com 
SYAIDATUN NAZIRAH ABU ZAHRIN

Pusat Citra Universiti \& The Institute of Islam Hadhari

Universiti Kebangsaan Malaysia

43600 UKM Bangi, Selangor, Malaysia

NURUL SHAHIRAH ABDUL SAMAD

Faculty of Economy and Muamalat

Universiti Sains Islam Malaysia

Bandar Baru Nilai, 71800 Nilai, Negeri Sembilan

Email: nurulshahirahabdulsamad17@gmail.com

*Corresponding author: syaidatun@ukm.edu.my 